\title{
Growth potential bioassay of water masses using diatom cultures: Phosphorescent Bay (Puerto Rico) and Caribbean waters*
}

\author{
T. J. SMAYDA \\ Graduate Scbool of Oceanography, University of Rbode Island; \\ Kingston, Rbode Island, USA
}

KURZFASSUNG: Bioassay des Wachstumspotentials von Wasserkörpern auf der Basis von Diatomeen-Kulturen: Phosphorescent Bay (Porto Rico) und karibische Gewässer. Zur biologischen Gütebeurteilung wurden mit Proben von Oberflächenwasser aus der Phosphorescent Bay (Porto Rico) Kulturen von Bacteriastrum byalinum, Cyclotella nana, Skeletonema costatum und Thalassiosira rotula angesetzt. Thalassiosira rotula und Bacteriastrum byalinum dienten außerdem als Testorganismen für Wasserproben aus der Karibischen See. Die Kulturmedien wurden mit verschiedenen Nährsalzen und Wirkstoffen angereichert, wodurch die Vermehrung der Diatomeen in sehr unterschiedlicher Weise stimuliert oder limitiert wurde. Es ergab sich, daß Oberflächenwasser stets toxisch gegenüber Bacteriastrum byalinum war, Cyclotella nana aber in allen Wasserproben gedieh. Die beiden anderen Arten zeigten unterschiedliches Verhalten. Trotz der relativ geringen Entfernungen der einzelnen Stationen in der Phosphorescent Bay $(2500 \mathrm{~m})$ traten bezüglich der Wasserqualität Unterschiede auf, die aus den hydrographischen Daten nicht hervorgingen, jedoch im Kulturexperiment anhand der Wachstumsrate der Diatomeen abgelesen werden konnten. Die Befunde werden im Hinblick auf allgemeine Probleme der Sukzession und Verteilung von Phytoplanktonarten diskutiert.

\section{INTRODUCTION}

Phosphorescent Bay (Bahía Fosforescénte), Puerto Rico (Fig. 1), is well-known for its intense dinoflagellate bioluminescence (CLARKE \& BRESLAU 1960) attributed to the nearly continuous bloom of Pyrodinium bahamense (MARgalef 1957). Other luminescent dinoflagellates also occur, sometimes in greater abundance than Pyrodinium (COKER \& GONZÁLEZ 1960, GLYNN et al. 1964, Gold 1965). Agitation of the water mass through wave, hand or boat movements causes an intense luminous discharge of the dinoflagellates, and rapidly swimming fishes are outlined with light. Clarke \& Breslau (1960) found a luminescent emission of $3 \times 10^{-2} \mu \mathrm{w}$ in the bow wave of a fast moving boat which exceeded the moonlight previously recorded (in air) from a quarter moon. Several national and international organizations have recommended that Phosphorescent Bay be preserved for public enjoyment and scientific

\footnotetext{
* This investigation was partly aided by National Science Foundation Grant GB - 5366 .
} 
study, and a plan for its preservation and use has recently been prepared by the U.S. Department of the Interior (ANONYMous 1968).

Phosporescent Bay is about 19 hectares in area, has a mean depth of $3.5 \mathrm{~m}$, and is connected with offshore (coral reef) waters through a shallow, narrow opening about $150 \mathrm{~m}$ wide* (Coker \& González 1960). The red mangrove, Rhizophora mangle, together with lesser stands of Avicennia nitida and Laguncularia racemosa, dominates a well-developed mangrove swamp ("manglare") along the margins of the embayment whose area of 19 hectares equals that of the open water (COKER \& GONZÁLEZ 1960). Mangrove development is especially pronounced in the innermost region, which it divides into three arms (Fig. 1). A canal from a commercial salt flat leads into the middle arm. Phosphorescent Bay lies within the rain shadow of the island. The annual average rainfall is about $75 \mathrm{~cm}$ (GLYNN et al. 1964), although, between 1956 and 1959, the annual rainfall varied from about 76 to $134 \mathrm{~cm}$ (see CoKER \& González 1960, MARgalef 1961). The surrounding drainage basin is poorly developed and covered with a xerophytic plant community, including cactus.

Hydrographic and chemical observations have been made (BURKHOLDER \& BURKholder 1958, CoKer \& González 1960, Margalef 1961, González 1967). Near station P10 (Fig. 1), the annual ranges in surface conditions were $26.5^{\circ}-31.1^{\circ} \mathrm{C}$ (GoNZÁLEZ 1967); about 34.5-37.0\% \% 0.06-0.56 $\mu$ g-at $\mathrm{PO}_{4}-\mathrm{P} \mathrm{I}^{-1}(\overline{\mathrm{X}}=0.32) ; 0.01-0.70$ $\mu \mathrm{g}$-at $\mathrm{NO}_{3}-\mathrm{N} \mathrm{I}^{-1}(\overrightarrow{\mathrm{X}}=0.12) ; 0.01-0.12 \mu \mathrm{g}$-at $\mathrm{NO}_{2}-\mathrm{N} \mathrm{I}^{-1}(\overline{\mathrm{X}}=\sim 0.10)$; and 0.34 $10.70 \mu \mathrm{g}$-at $\mathrm{SiO}_{3}-\mathrm{Si} \mathrm{I}^{-1}(\overline{\mathrm{X}}=4.37)$. The Secchi Disc disappearance depth ranged from 0.9 to $3.4 \mathrm{~m}(\bar{X}=\sim 2.0$ ), from which an extinction coefficient (" $k$ ") range of 0.5 to 2.0 and mean of 0.85 can be calculated. The high turbidity of Phosphorescent Bay is attributable to high phytoplankton concentrations; debris from the mangrove swamps; periodic land drainage after heavy rainfall; and stirring up of the loose sediments by fish (BURKHOLDER \& BURKHOLDER 1958, GONZÁLEZ 1967). Relatively high vitamin $B_{12}$ concentrations accompany this turbidity (BURKHOLDER \& BURKHOLDER 1958, GOLD 1965).

The environmental studies to date do not adequately explain the continued predominance of dinoflagellates in Phosphorescent Bay. A "trap" mechanism in which offshore water flows inwards, to compensate for water losses due to evaporation and mangrove transpiration (MARGALEF 1961); the accretion of nutrients through drainage, supplemented by significant vitamin production in situ (BURKHOLDER \& BURKHOLDER 1958); and the flushing rate (ANonYMous 1968) have been proposed as important factors.

Evidence for the continuous pre-eminence of dinoflagellates is based primarily on Margalef's $(1957,1961)$ annual net phytoplankton survey, which suggests that a large Coscinodiscus sp. is also important (other pelagic diatoms were scarce). However, Skeletonema costatum dominated the intense diatom bloom found in adjoining waters following hurricane Edith on 26-27 September, 1963 (GLYNN et al. 1964). The rainfall of $20 \mathrm{~cm}$ was about $25 \%$ of the mean annual precipitation. Bioluminescence intensity in Phosphorescent Bay temporarily decreased significantly following this

* Other authors report the opening is only about 100 meters wide (Burkholder \& Burkholder 1958, Clarke \& Bresl.au 1960). 
storm, when Ceratium furca greatly outnumbered Pyrodinium babamense. Phytoflagellate blooms other than dinoflagellates and ${ }^{14} \mathrm{C}$ productivity results have been reported (BurkHolder et al. 1967). MARGALEF's (1961) annual production estimate of $20-40 \mathrm{~g} \mathrm{C} \mathrm{m}^{-2}$ based on chlorophyll a concentrations appears to be 2 to 3 fold (possibly 5 fold) lower than that based on ${ }^{14} \mathrm{C}$ assimilation (GoNzÁLEz 1967).

CoKer \& GonzÁLEZ (1960) found the embayment to be less favorable than the outer, reef waters for most zooplankton species, except for Oithona minima and Acartia tonsa. They imply that the intense development of the luminescent dinoflagellates might reflect a relaxation in predation pressure. Gold (1965) used 4 diatom bioassay species to test water, collected in February from an undisclosed location and depth in Phosphorescent Bay, for the presence of diatom inhibiting compounds.

The results of a brief hydrographic survey at 12 stations in Phosphorescent Bay during 12-13 November, 1963, and nutrient enrichment experiments at 3 stations using Bacteriastrum byalinum, Cyclotella nana (13-1), Skeletonema costatum and Thalassiosira rotula as bioassay diatoms will be presented in this paper. The goals of the bioassay experiments were: (1) to evaluate whether the apparent unimportance of diatoms might be due to the chemical water quality of Phosphorescent Bay; (2) to examine whether small scale "chemical patchiness" occurs in the growth supporting potential of a water mass for different species; and (3) technique development.

Nutrient enrichment experiments were also conducted with Thalassiosira rotula at 14 of 18 stations occupied by R/V "Trident" during Cruise No. 12 ("Columbo") between the Southwestern Puerto Rican coast and Western Haiti during 13-20 November, 1963. Bacteriastrum byalinum was also used as a bioassay diatom at 4 stations. The Caribbean experiments are part of a general study of the influence of regional differences in water quality on the growth and distribution of diatoms (SMAYDA 1970, in preparation). I wish to acknowledge the assistance of Miss B. J. BoLEYN during all phases of the investigation. Dr. R. R. L. GuILlaRd provided the Cyclotella nana (13-1) culture.

\section{MATERIALS AND METHODS}

Station locations and hydrographic conditions in Phosphorescent Bay (Fig. 1) and in the Caribbean Sea (Fig. 2) are presented in Tables 1 and 2. Stations at which enrichment experiments were conducted in Phosphorescent Bay are identified as P1, P10 and P12. Standard techniques were used for the salinity, oxygen, phosphate and nitrate determinations. The oxygen saturation values were computed from Fox's wellknown tables. The extinction coefficient ("k") was calculated from the Poole \& AtKIns (1929) formula:

$$
k=1.7 / D
$$

where $D$ equals the Secchi Disc disappearance depth in meters.

Bioassay station P12 was located in very clear water (Table 1) $3 \mathrm{~m}$ deep in a break between a coral reef about $1,500 \mathrm{~m}$ offshore from the entrance into Phosphorescent Bay. Innermost station P1 was located in a shallow (about $1.5 \mathrm{~m}$ ), very turbid mangrove backwater (Fig. 1) about $2,500 \mathrm{~m}$ from station P12, and about $750 \mathrm{~m}$ 


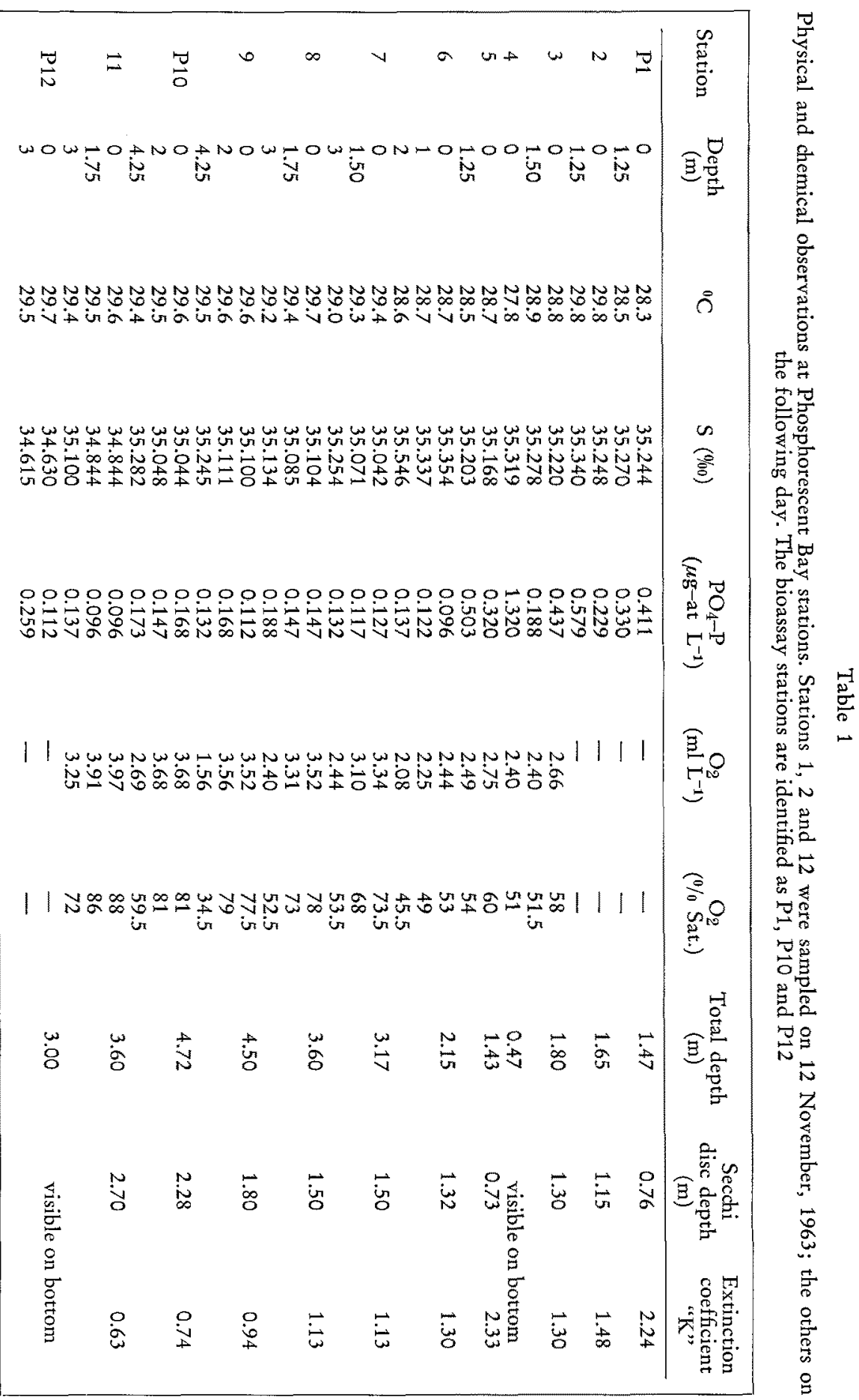


inwards from station P10 located in mid-bay in approximately $4.7 \mathrm{~m}$ (Table 1). Thus, the bioassay stations comprise a gradient from turbid, mangrove swamp-modified water (P1), to "intermediate" (P10) to outer, coral reef water (P12).

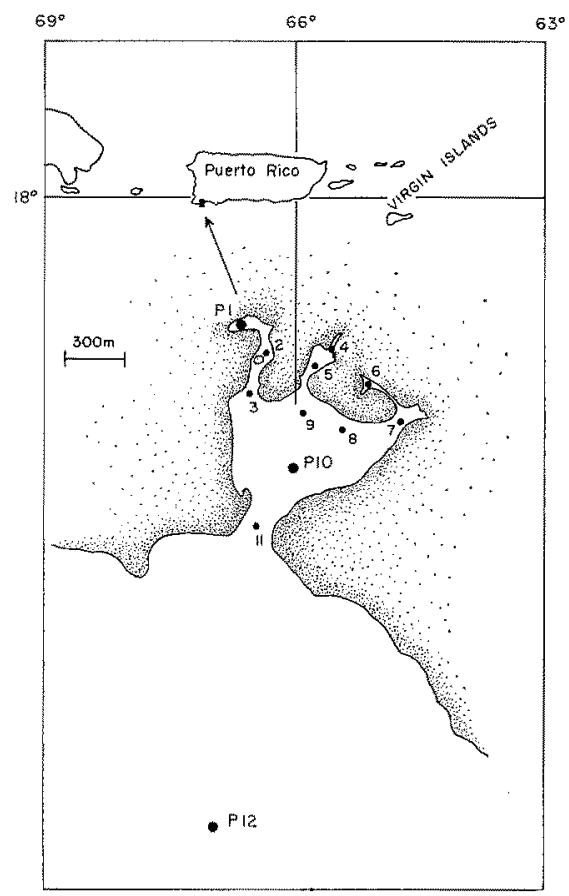

Fig. 1: Station locations in Phosphorescent Bay, Puerto Rico. Stations P1, P10 and P12 are locations where surface water was collected for the nutrient enrichment experiments

The Caribbean transect was designed to monitor different nearshore and oceanic water types, the influence of "land mass", and run off (station 19) from one of the larger rivers (Yaque del Sur) draining into the Northern Caribbean.

For the enrichment experiments, s u $\mathrm{rface}$ water (collected with a 41 glass sampling bottle in Phosphorescent Bay and an 81 Niskin bottle on the Caribbean transect) was filtered through sterile, glass fiber filters of $0.45 \mu$ average pore size to remove the natural plankton population and debris. In the Cyclotella nana (13-1) bioassay experiments, $15 \mathrm{ml}$ aliquots of the $\mathrm{fil}$ t e $\mathrm{r}$ e d water were dispensed aseptically into transparent $30 \mathrm{ml}$ pre-sterilized, disposable, styrene tissue culture flasks (SMAYDA 1964). For the other bioassay diatoms, $7.5 \mathrm{ml}$ aliquots were dispensed aseptically into sterile, glass culture tubes $(16 \times 125 \mathrm{~mm})$. At each station, 6 to 8 different nutrient enrichments were made for the Bacteriastrum byalinum, Skeletonema costatum, and Thalassiosira rotula experiments, and 14 enrichments for Cyclotella nana (13-1). The nutrient levels used are indicated in Table 3. The enrichment schedule was as follows: (1) NONE (i. e. no enrichment); (2) ALL (ingredients 1 to 6 in Table 3); (3) AlL-P; (4) AlI-N; (5) All-Si; (6) All-FeEDTA + NagEDTA (1 mg/l); (7) All-TM; (8) All-vitamins. 


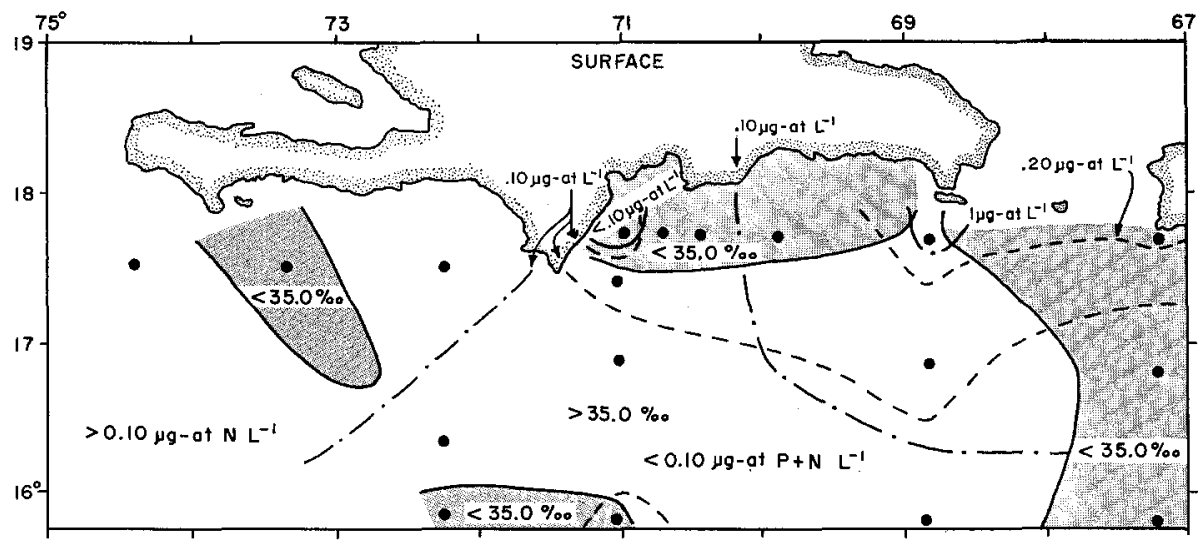

Fig. 2: Surface hydrographic conditions at the Caribbean stations sampled during 13th-20th November, 1963

These additional enrichments were made for the Cyclotella nana (13-1) experiments: (9) All-Fe; (10) P, N, Si, FeEDTA; (11) N, Si, FeEDTA; (12) P, Si, FeEDTA; (13) P, N, FeEDTA; (14) P, N, Si.

The culture flasks were in divid u a lly inoculated with the bioassay diatoms employing the following procedure. Stock cultures of unialgal Bacteriastrum byalinum, Skeletonema costatum and Thalassiosira rotula, isolated by the author from Narragansett Bay, Rhode Island ( $\left.41^{\circ} 30^{\prime} \mathrm{N}, 71^{\circ} 25^{\prime} \mathrm{W}\right)$, and axenic Cyclotella nana (13-1), origi-

Table 2

Location, date of collection and physical-chemical properties of surface samples collected in the Caribbean Sea during 12-20 November, 1963, for use in the Thalassiosira rotula and Bacteriastrum hyalinum (only stations 10-14) bioassay experiments

\begin{tabular}{|c|c|c|c|c|c|c|}
\hline Station & Date & Location & ${ }^{\circ} \mathrm{C}$ & $\mathrm{S}(\%)$ & $\begin{array}{r}\mathrm{PO}_{4}-\mathrm{P} \\
(\mu \mathrm{g}\end{array}$ & $\begin{array}{l}\mathrm{NO}_{3}-\mathrm{N} \\
\left.1^{-1}\right)\end{array}$ \\
\hline 10 & 13. XI & $17^{0} 53^{\prime} \mathrm{N}, 67^{0} 12^{\prime} \mathrm{W}$ & 28.94 & 34.748 & 0.20 & 0.14 \\
\hline 11 & 14. XI & $17^{\circ} 00^{\prime} \mathrm{N}, 67^{\circ} 12^{\prime} \mathrm{W}$ & 28.72 & 34.911 & 0 & 0.21 \\
\hline 12 & 14. XI & $16^{\circ} 00^{\prime} \mathrm{N}, 67^{\circ} 12^{\prime} \mathrm{W}$ & 28.98 & 34.870 & 0.03 & 0 \\
\hline 14 & 15. XI & $16^{0} 04^{\prime} \mathrm{N}, 69^{\circ} 16^{\prime} \mathrm{W}$ & 28.68 & 35.313 & 0.04 & 0 \\
\hline 15 & 16. XI & $17^{0} 04^{\prime} \mathrm{N}, 69^{\circ} 13^{\prime} \mathrm{W}$ & 28.73 & 35.303 & 0.14 & 0.21 \\
\hline 16 & 17. XI & $18^{\circ} 07^{\prime} \mathrm{N}, 69^{\circ} 13^{\prime} \mathrm{W}$ & 28.43 & 35.014 & 0.24 & 1.08 \\
\hline 17 & 17. XI & $18^{\circ} 07^{\prime} \mathrm{N}, 69^{\circ} 52^{\prime} \mathrm{W}$ & 28.30 & 34.941 & 0.11 & 0.21 \\
\hline 18 & 17. XI & $18^{\circ} 07^{\prime} \mathrm{N}, 70^{\circ} 25^{\prime} \mathrm{W}$ & 28.34 & 34.808 & 0.10 & 0 \\
\hline $18 \mathrm{~A}$ & 17. XI & $18^{\circ} 07^{\prime} \mathrm{N}, 70^{\circ} 42^{\prime} \mathrm{W}$ & 28.62 & 34.808 & 0.12 & - \\
\hline 19 & 17. XI & $18^{\circ} 07^{\prime} \mathrm{N}, 70^{\circ} 57^{\prime} \mathrm{W}$ & 28.84 & 34.310 & 0.07 & 0 \\
\hline 20 & 18. XI & $17^{0} 36^{\prime} \mathrm{N}, 70^{\circ} 58^{\prime} \mathrm{W}$ & 28.45 & 35.037 & 0.13 & - \\
\hline 21 & 18. XI & $17^{\circ} 04^{\prime} \mathrm{N}, 70^{\circ} 58^{\prime} \mathrm{W}$ & 28.41 & 35.042 & 0.04 & 0 \\
\hline 22 & 18. XI & $16^{\circ} 00^{\prime} \mathrm{N}, 70^{\circ} 59^{\prime} \mathrm{W}$ & 28.40 & 34.994 & 0.11 & - \\
\hline 23 & 19. XI & $16^{0} 00^{\prime} \mathrm{N}, 72^{\circ} 12^{\prime} \mathrm{W}$ & 28.36 & 34.949 & 0.05 & 0 \\
\hline 24 & 19. XI & $16^{0} 50^{\prime} \mathrm{N}, 72^{\circ} 12^{\prime} \mathrm{W}$ & 28.44 & 35.127 & 0.05 & 0 \\
\hline 25 & 19. XI & $17^{\circ} 41^{\prime} \mathrm{N}, 72^{0} 12^{\prime} \mathrm{W}$ & 28.80 & 35.308 & 0.02 & 0.21 \\
\hline 26 & 19. XI & $17^{0} 42^{\prime} \mathrm{N}, 73^{0} 19^{\prime} \mathrm{W}$ & 28.37 & 34.773 & 0.02 & - \\
\hline 27 & 20. XI & $17^{\circ} 40^{\prime} \mathrm{N}, 74^{\circ} 23^{\prime} \mathrm{W}$ & 28.52 & 35.240 & 0.02 & 0.56 \\
\hline
\end{tabular}


Table 3

Medium used to maintain stock cultures and in the bioassay experiments

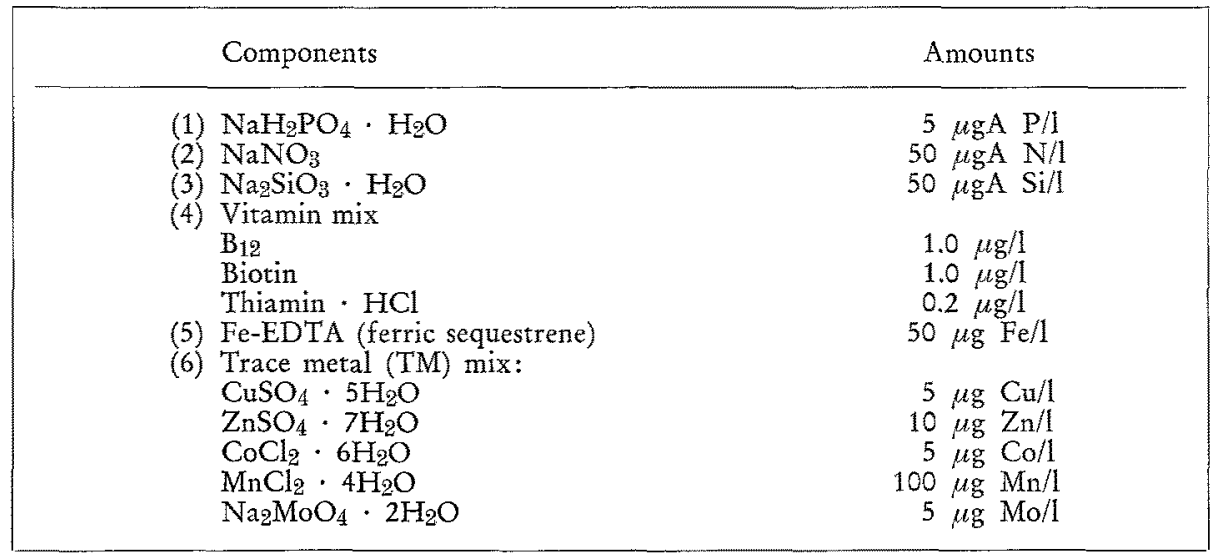

nally isolated from the Sargasso Sea by Guillard (Guillard \& Ryther 1962), were maintained on board ship in enriched (Table 3) Narragansett Bay water. For use in the bioassay experiments, log-phase cells were first transferred into sterile, filtered, unenriched Sargasso Sea water to induce nutrient limitation and, secondarily, to minimize nutrient carryover with the inoculum. The inoculum (based on a haemocytometer count) taken from a 5 to 7 day old culture varied from 1,600 to 3,400 cells ml-1 for B. byalinum; it was about 3,950 cells $\mathrm{ml}^{-1}$ for C. nana; varied from 2,120 to 2,500 cells $\mathrm{ml}^{-1}$ for $S$. costatum; and from 1,800 to 3,200 cells ml-1 for $T$. rotula. It was constant at a given station. In the Caribbean experiments, the inoculum varied from about 400 to 3,200 cells $\mathrm{ml}^{-1}$, a range without apparent effect on the relative growth response. When transferred into Sargasso Sea water for pre-treatment, slow growth, provided an insufficient inoculum and prevented the B. byalinum bioassay from being carried out after station 14 (Fig. 3).

The culture flasks were incubated for 5 days at $20^{\circ} \mathrm{C}$ and about 700 foot-candles of continuous, artificial illumination from cool-white fluorescent lamps. The experiments were terminated by fixing with a few drops of Lugol's solution. The population was then enumerated ashore, to evaluate the growth response. A haemocytometer was used to count Cyclotella nana and Skeletonema costatum, and a Palmer-Maloney chamber for Bacteriastrum byalinum and Thalassiosira rotula. Duplicate counts were made for each experiment. The change in cell numbers relative to the inoculum size is used as a measure of growth. Growth will usually refer to an increase in cell number above that of the inoculum, while inhibition will mean a d e c rease in the inoculated population.

The autecological characteristics of Cyclotella nana (13-1) (SMAYda 1964) and Skeletonema costatum (BRAARUD 1962) have been summarized previously, whereas little is known about Bacteriastrum byalinum and Thalassiosira rotula. Cyclotella nana $(13-1)$ can be characterized as a stenohaline and stenothermal, warm water, oceanic species; Skeletonema costatum as euryhaline and eurythermal; Thalassiosira rotula has 


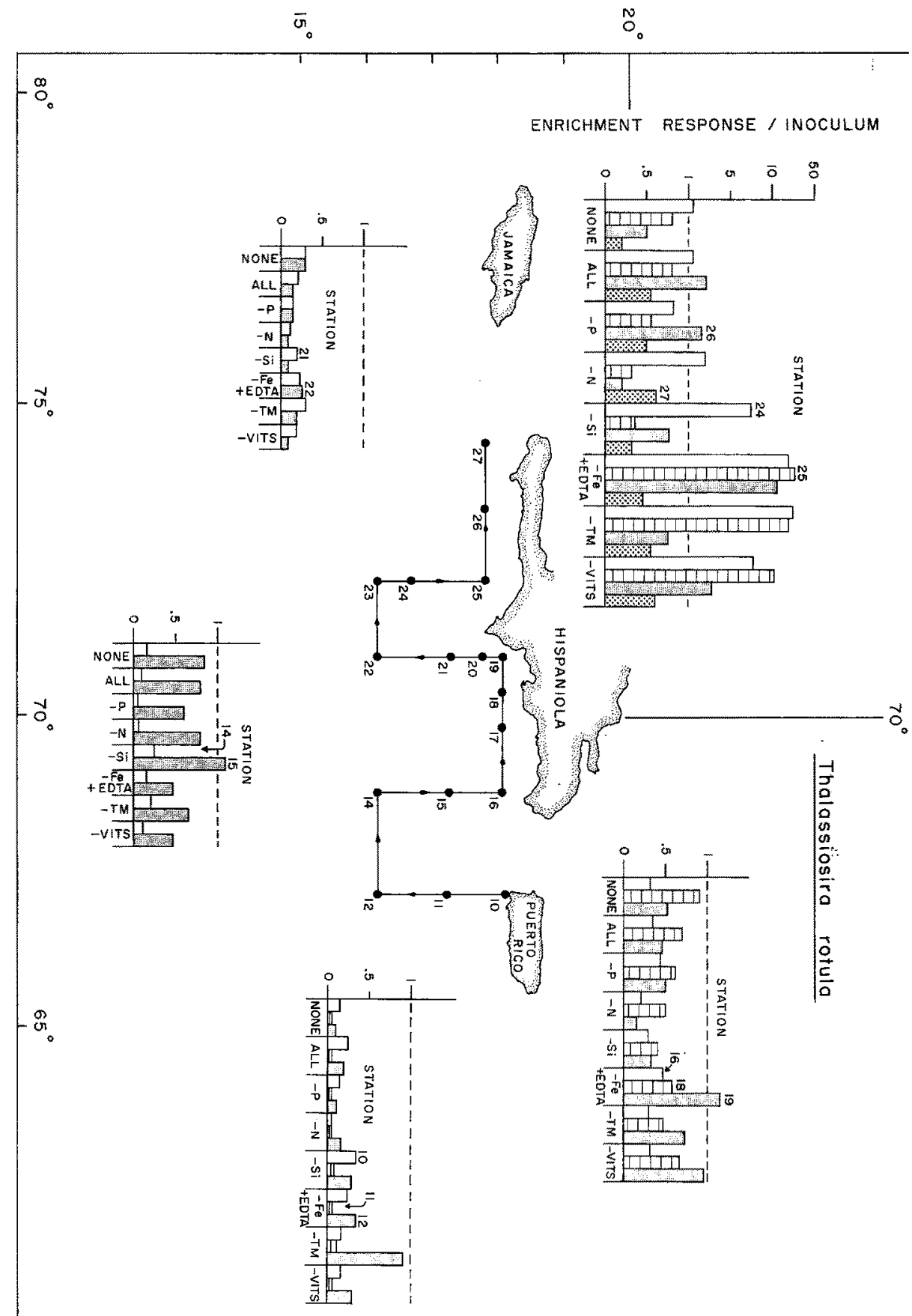

Fig. 3: Location and results of the nutrient enrichment experiments in the Caribbean Sea using surface water and Thalassiosira rotula as bioassay diatom. Histograms extending above the dotted line represent growth promotion by the nutrient treatment. Nutrients preceded by (i.e., $-N$ ) represent the omission of that nutrient from the complete enrichment (ALL). TM $=$ trace metal mixture; VITS = vitamin mixture. Hydrographic observations only were made at stations 17,20 and 23 
attained a July maximum in Narragansett Bay at $17^{\circ} \mathrm{C}$ (SMAYda 1957); and Bacteriastrum byalinum is a common, tropical inshore species which is sometimes a summer visitor in temperate waters.

Cyclotella nana (13-1) and Thalassiosira rotula have not been reported from Phosphorescent Bay. Bacteriastrum byalinum and Skeletonema costatum were recorded during July in one of the 37 net tows collected during an annual survey (MARGaleF $1957,1961)$. The latter may periodically occur in greater abundance in contiguous coastal waters, and dominated the post-hurricane bloom observed about 6 weeks before the Phosphorescent Bay survey (GLYNN et al. 1964). B. byalinum can be expected to occur in the Caribbean bioassay survey area (Takano 1960); there are insufficient observations on $T$. rotula to evaluate the probability of its occurrence there.

\section{RESULTS}

\section{Hydrography of Phosphorescent Bay}

Surface temperatures ranged from $27.8^{\circ}$ to $29.8^{\circ} \mathrm{C}$; salinity from $34.844 \%$ to $33.354 \%$; phosphate from .096 to $1.32 \mu \mathrm{g}$-at $\mathrm{l}^{-1}$; and dissolved oxygen was at $51 \%$ to $88 \%$ saturation (Table 1 ). Slight differences occurred with depth; but the water mass, generally, was only weakly stratified. Shallow station P1 (located in a mangrove backwater) is slightly warmer, saltier, and richer in phosphate by 3.5 fold than station P12 located near a coral reef 1,500 m away from Phosphorescent Bay (Table 1, Fig. 1). Station P10 is intermediate between these extremes. Station P1 is also considerably more turbid. The Secchi Disc readings ranged from about $0.75 \mathrm{~m}$ (P1) to visibility at the bottom $(3 \mathrm{~m})$ at station P12; the extinction coefficient (" $\mathrm{k}$ "), where calculable, varied from 0.63 to 2.33 . Higher oxygen levels generally accompanied increased transparency.

The Phosphorescent Bay stations are characterized, therefore, by a conspicuous offshore gradient in surface water features (Table 1) in which there is: (1) a slight temperature increase; (2) a decrease in both salinity and phosphate; and (3) a pronounced increase in transparency. These general trends agree with previous hydrographic observations.

\section{Bioassay experiments with Phosphorescent Bay water}

\section{Bacteriastrum byalinum}

Bacteriastrum byalinum did not grow in the $\mathrm{u}$ e $\mathrm{n} \mathrm{r}$ ich ed surface samples, nor did any nutrient modification permit growth relative to the inoculum (Table 4). In fact, marked inhibition reduced the initial population to about $25 \%$ of the inoculum at stations P1 and P12. Survival without growth occurred at station P10 where inhibition was not as pronounced with enrichment. Some enrichments, such as phosphate omission at station P12, even heightened mortality. 
Table 4

Growth of Bacteriastrum byalinum, Thalassiosira rotula and Skeletonema costatum relative to inoculum in various enrichments of surface water collected within and near the entrance to Phosphorescent Bay, Puerto Rico, on 12-13 November, 1963

\begin{tabular}{|c|c|c|c|c|}
\hline Species & Enrichment & P1 & $\begin{array}{c}\text { Stations } \\
\text { P10 }\end{array}$ & P12 \\
\hline $\begin{array}{l}\text { Bacteriastrum } \\
\text { byalinum }\end{array}$ & $\begin{array}{l}\text { None } \\
\text { AlL } \\
\text { ALL-P } \\
\text { AlL-N } \\
\text { ALL-Si } \\
\text { ALL-Fe+NagEDTA } \\
\text { AlL-TM } \\
\text { AlL-VITS } \\
\text { Inoculum (cells } \mathrm{ml}^{-1} \text { ) }\end{array}$ & $\begin{array}{r}0.28 \\
0.25 \\
0.28 \\
0.14 \\
0.27 \\
0.12 \\
- \\
-\end{array}$ & $\begin{array}{l}1.04 \\
0.77 \\
0.57 \\
0.77 \\
0.77 \\
0.70 \\
0.62 \\
0.62 \\
3460\end{array}$ & $\begin{array}{c}0.24 \\
0.19 \\
0.06 \\
0.37 \\
0.11 \\
0.20 \\
\overline{-} \\
1600\end{array}$ \\
\hline $\begin{array}{l}\text { Thalassiosira } \\
\text { rotula }\end{array}$ & $\begin{array}{l}\text { NoNE } \\
\text { ALL } \\
\text { ALL-P } \\
\text { ALL-N } \\
\text { ALL-Si } \\
\text { ALL-Fe+Na2EDTA } \\
\text { ALL-TM } \\
\text { ALL-VITS } \\
\text { Inoculum (cells ml-1) }\end{array}$ & $\begin{array}{r}3.03 \\
30.29 \\
6.06 \\
1.82 \\
23.63 \\
36.95 \\
= \\
1880\end{array}$ & $\begin{array}{l}0.50 \\
0.20 \\
0.28 \\
0.26 \\
0.30 \\
0.20 \\
0.33 \\
0.24 \\
3200\end{array}$ & $\begin{array}{c}0.0 \\
0.28 \\
5.57 \\
0.14 \\
0.11 \\
18.64 \\
\overline{-} \\
1880\end{array}$ \\
\hline $\begin{array}{l}\text { Skeletonema } \\
\text { costatum }\end{array}$ & $\begin{array}{l}\text { NonE } \\
\text { ALI } \\
\text { ALL-P } \\
\text { ALL-N } \\
\text { ALL-Si } \\
\text { ALL-Fe+NagEDTA } \\
\text { ALL-TM } \\
\text { ALL-VITS } \\
\text { Inoculum (cells ml }{ }^{-1} \text { ) }\end{array}$ & $\begin{array}{c}0.04 \\
0.14 \\
0.01 \\
0.07 \\
0.13 \\
0.29 \\
- \\
\overline{-} \\
2120\end{array}$ & $\begin{array}{r}1.78 \\
48.56 \\
45.20 \\
23.69 \\
48.74 \\
4.93 \\
3.95 \\
19.34 \\
2533\end{array}$ & $\begin{array}{r}5.67 \\
57.08 \\
3.30 \\
15.80 \\
136.82 \\
0.0 \\
= \\
2120\end{array}$ \\
\hline
\end{tabular}

Relative to growth in the complete enrichment $(A L L)$, several gradients in response accompanied the omission of certain nutrients (Table 5). Omitting phosphate, Bacteriastrum byalinum growth progressively decreased from $110 \%$ of that in All at P1 to $33 \%$ at the phosphate poorer, less saline and more transparent station P12. The trend was less pronounced with silicate omission. Growth progressively improved with nitrate omission from only $50 \%$ of that in ALI at station P1, to stimulation (193\%) at station P12. A similar, less pronounced, trend characterized iron (with EDTA added) omission. Chlorotic cells developed in nearly all enrichments.

\section{Thalassiosira rotula}

Thalassiosira rotula grew well in the $\mathrm{u}$ e $\mathrm{n} \mathrm{rich}$ ed water from station P1; while $50 \%$ and complete mortality of the inoculum occurred at stations P10 and P12 (Table 4). Complete enrichment improved growth 10 fold at station P1, which varied (as cell number) from this by about $20 \%$ when silicate and iron (but with $1 \mathrm{mg} \mathrm{m}^{-1}$ 
Table 5

Growth response of Bacteriastrum byalinum, Thalassiosira rotula and Skeletonema costatum in various enrichments relative to growth in complete enrichment (ALL) at Stations P1, P10 and P12

\begin{tabular}{|c|c|c|c|c|}
\hline Species & Enrichment & P1 & $\begin{array}{l}\text { Ptations } \\
\text { P10 }\end{array}$ & P12 \\
\hline $\begin{array}{l}\text { Bacteriastrum } \\
\text { byalinum }\end{array}$ & $\begin{array}{l}\text { NonE } \\
\text { ALL-P } \\
\text { ALL-N } \\
\text { ALL-Si } \\
\text { ALL-Fe+Na2EDTA } \\
\text { ALL-TM } \\
\text { ALL-VITS }\end{array}$ & $\begin{array}{l}1.10 \\
1.10 \\
0.55 \\
1.09 \\
0.46 \\
-\end{array}$ & $\begin{array}{l}1.35 \\
0.74 \\
1.00 \\
1.00 \\
0.91 \\
0.82 \\
0.81\end{array}$ & $\begin{array}{l}1.27 \\
0.33 \\
1.93 \\
0.60 \\
1.07 \\
- \\
-\end{array}$ \\
\hline $\begin{array}{l}\text { Thalassiosira } \\
\text { rotula }\end{array}$ & $\begin{array}{l}\text { NonE } \\
\text { ALL-P } \\
\text { ALL-N } \\
\text { ALL-Si } \\
\text { ALL-Fe+Na2EDTA } \\
\text { ALL-TM } \\
\text { ALL-VITS }\end{array}$ & $\begin{array}{l}0.01 \\
0.20 \\
0.06 \\
0.78 \\
1.22 \\
-\end{array}$ & $\begin{array}{l}2.48 \\
1.41 \\
1.26 \\
1.49 \\
0.98 \\
1.67 \\
1.22\end{array}$ & $\begin{array}{l}0 \\
19.91 \\
0.51 \\
0.38 \\
66.56 \\
-\end{array}$ \\
\hline $\begin{array}{l}\text { Skeletonema } \\
\text { costatum }\end{array}$ & $\begin{array}{l}\text { NonE } \\
\text { ALL-P } \\
\text { ALL-N } \\
\text { ALL-Si } \\
\text { ALL-Fe+NagEDTA } \\
\text { ALL-TM } \\
\text { ALL-VITS }\end{array}$ & $\begin{array}{l}0.29 \\
0.09 \\
0.48 \\
0.88 \\
2.03 \\
-\end{array}$ & $\begin{array}{l}0.04 \\
0.93 \\
0.49 \\
1.02 \\
0.10 \\
0.40 \\
0.08\end{array}$ & $\begin{array}{l}0.10 \\
0.06 \\
0.28 \\
2.38 \\
0 \\
= \\
-\end{array}$ \\
\hline
\end{tabular}

of NagEDTA present) were omitted. Phosphate and, particularly, nitrate omission significantly limited growth; the latter reduced growth to below that of the unenriched sample.

Enriched station P10 water became even more inimical (about $75 \%$ mortality) to Thalassiosira rotula than the $50 \%$ mortality of the unenriched sample; the cells were very chlorotic. At station P12, omission of phosphate and, especially, iron (with EDTA present) markedly stimulated growth. A feeble, inhibited response accompanied the other treatments. Normally chain forming, $T$. rotula was predominantly unicellular in the station P12 experiments.

Relative to growth in All (Table 5), Thalassiosira rotula exhibited an offshore gradient to phosphate omission. At $\mathrm{P} 1$, growth decreased to $20 \%$ of that in the complete enrichment, but was stimulated by about 1.4 fold and 20 fold at stations P10 and $\mathrm{P} 12$. This trend is the converse of that found for Bacteriastrum byalinum with phosphate omission.

\section{Skeletonema costatum}

The response of Skeletonema costatum in the $\mathrm{u} \mathrm{n}$ e $\mathrm{n} \mathrm{ich}$ ed samples relative to the inoculum was the reverse of that by Thalassiosira rotula (Table 4). That is, an offshore gradient of progressively improved water quality permitted its growth with- 
out nutrient modification. Thus, at station $\mathrm{P} 1$, virtually complete mortality of the inoculum occurred which was not released by any of the nutrient enrichments. Good growth occurred at station P10 (178\%) and improved significantly at station P12 $(567 \%)$. Growth was further stimulated about 24 and 10 fold at stations P10 and P12 in the complete nutrient (ALL) enrichment.

At station P10, neither phosphate nor silicate omission influenced growth. Growth decreased 10 to 12 fold when the iron (with EDTA present) and trace metal rations were omitted, but still exceeded that in the unenriched sample by about 2 to 3 fold.

Several responses also occurred at station P12 (Table 4). $\mathrm{O} m$ is s i o $\mathrm{n}$ of silicate markedly stimulated growth (136 fold) above that with All. This was the maximum population density observed in the entire bioassay series. The ALL-Si and Alt enrichments also produced the maximum Skeletonema costatum populations at station P10 (Table 4). Phosphate omission, however, limited growth $(330 \%)$ which was poorer than that in the unenriched treatment. The omission of neither nutrient influenced growth at station P10. Growth decreased about 3.5 fold with nitrate omission. Surprisingly, growth was not evident when iron (with EDTA added) was omitted; in fact, complete mortality seems likely! This response differs from that at station $\mathrm{P} 10$ where, despite iron limitation ( $\sim 10$ fold below ALL), growth was still about 3 fold greater than that of the unenriched assay.

Relative to growth in All (Table 5), an offshore gradient occurred in response to silicate omission (progressive growth improvement) and iron omission (progressive growth impairment).

Skeletonema costatum exhibited considerable size variations in the different enrichments and, like Thalassiosira rotula, seemed incapable of forming chains in station P12 water, in which a maximum of two cells per chain was found.

\section{Cyclotella nana (13-1)}

The nutrient enrichment treatments used in the Cyclotella nana (13-1) experiments also included various combinations of phosphate, nitrate, silicate and FeEDTA without addition of the trace metal or vitamin mixes (Table 6). Of the 4 bioassay diatoms used, $C$. nana was best suited for survival in the range in water quality found in Phosphorescent Bay. Un e $\mathrm{n} \mathrm{i}$ ch ed water from within the bay, supported better growth (relative to inoculum size) than for any of the other species, except Thalassiosira rotula at station P1 (Tables 4 and 6). Unen riched water from station P12 did not permit growth (complete mortality is suggested) until enriched, particularly with All or the phosphate + nitrate + silicate treatment. The excellent growth $(\sim 24$ fold $>$ inoculum) was still only $50 \%$ of that at station P10 with ALL, but about 6 fold greater than that at station P1. Thus, the rank order of growth with ALL was P10 $>$ $\mathrm{P} 12>\mathrm{P} 1$.

A combination of nutrient limitation and inhibition (through addition) influenced growth at station $\mathrm{P} 1$, even though growth occurred in the unenriched sample. At stations P10 and P12 nutrient limitation was more important. At P1 the omission of the chelator EDTA from Arx severely limited growth; as did silicate, nitrate and, to 
Table 6

Growth of Cyclotella nana (13-1) in various enrichments of surface water collected within and near the entrance to Phosphorescent Bay, Puerto Rico, on 12-13 November, 1963, relative to the inoculum

\begin{tabular}{|c|c|c|c|}
\hline Enrichment & P1 & $\begin{array}{c}\text { Stations } \\
\text { P10 }\end{array}$ & P12 \\
\hline None & 1.77 & 4.37 & 0 \\
\hline ALL & 3.94 & 48.60 & 24.62 \\
\hline ALL-P & 8.90 & 4.86 & 0.49 \\
\hline ALL-N & 0.91 & 3.89 & 5.65 \\
\hline ALL-Si & 0.39 & 3.89 & 3.45 \\
\hline ALL-FeEDTA & 0.12 & 20.42 & 0.74 \\
\hline $\mathrm{ALL}-\mathrm{Fe}+\mathrm{Na}{ }_{2} \mathrm{EDTA}$ & 4.18 & 11.66 & 0.98 \\
\hline ALL-TM & 1.65 & 1.46 & 0.74 \\
\hline ALL-VITS & 2.46 & 0 & 22.90 \\
\hline $\mathrm{P}, \mathrm{N}, \mathrm{Si}, \mathrm{FeEDTA}$ & 13.20 & 10.69 & 7.88 \\
\hline $\mathrm{N}, \mathrm{Si}, \mathrm{FeEDTA}$ & 10.28 & 3.89 & 9.36 \\
\hline $\mathrm{P}, \mathrm{Si}, \mathrm{FeEDTA}$ & 2.29 & 5.35 & 7.39 \\
\hline P, N, FeEDTA & 1.77 & 7.29 & 9.36 \\
\hline $\mathrm{P}, \mathrm{N}, \mathrm{Si}$ & 8.27 & 1.46 & 19.45 \\
\hline Inoculum (cells $\mathrm{ml}^{-1}$ ) & 3933 & 3945 & 3993 \\
\hline
\end{tabular}

a lesser extent, the trace metal mix. Phosphate omission, however, stimulated growth by $\sim 2$ fold above that with ALL, as also found at station P12 for Thalassiosira rotula (Table 4). Vitamin omission at station $\mathrm{P} 10$, surprisingly, prevented growth, otherwise limited by trace metal omission and, to a lesser extent, by nitrate and silicate. At station P12 omission (singly) of phosphate, iron (but not EDTA, unlike at station P1), and the trace metal mix strongly limited growth.

The nutrient enrichment experiments (Table 6) in which both the trace metal and vitamin mixes were omitted, and the remaining nutrients omitted sequentially (BSM series), are somewhat confusing. The phosphate + nitrate + silicate + FeEDTA combination at station P1 stimulated growth of Cyclotella nana to about 3 fold above that with ALL. This suggests that either the vitamin or trace metal mixes in the complete enrichment are inhibitory, or the natural concentrations were increased to inhibitory levels. But this is not confirmed by the relevant experiments which, in fact, suggest trace metal limitation (vitamin omission without effect). Maximum growth with the BSM series was about $25 \%$ of that with ALl at station P10, whereas the phosphate + nitrate + silicate enrichment at station P12 elicited growth of about $85 \%$ of that with ALL and AlL-vitamins. However, inconsistencies at stations P10 and P12 similar to those at P1 occurred, which probably partly reflect complicated synergistic relationships between the added and original nutrient levels, and chelation activities of the FeEDTA.

Gradients in influence of various nutrients relative to complete enrichment, such as noted for the other bioassay diatoms (Table 5), were not observed for Cyclotella nana (13-1). Cell size variations were commonplace from enrichment-to-enrichment treatment, but not consistent for a given treatment, as found previously with silicate omission (SMAYDa 1964). 


\section{Hydrography of the Caribbean Sea}

The surface hydrographic conditions at the Caribbean stations are presented in Figure 2 and Table 2. The temperature ranged from $28.30^{\circ}$ to $28.98^{\circ} \mathrm{C}$; salinity from $34.310 \%$ to $35.308 \% ; \mathrm{PO}_{4}-\mathrm{P}$ and $\mathrm{NO}_{3}-\mathrm{N}$ from undetectable levels to 0.24 and $1.08 \mu \mathrm{g}$-at $\mathrm{l}^{-1}$, respectively. Salinity below $35.0 \%$ characterized the transect (stations 10-12) South of Puerto Rico, and along the Dominican Republic coast where it progressively decreased Westwards to the lowest recorded value of $34.310 \%$ at station 19 located near the mouth of one of the larger rivers (Yaque del Sur) which drains into the Northern Caribbean. A swath of $<35.0 \%$ water (in which station 26 lies), also extends South-Eastwards from the coast of Haiti; a similar freshening characterizes outer stations 22 and 23. This distribution circumscribes a central water mass of slightly higher salinity. The surface salinity pattern does not particularly agree with that presented by PARR (1935), or by WÜST (1964) in his average surface diagram for this season. However, closer agreement exists with the $1^{0}$ quadrangle averages presented by WüsT.

Phosphate levels were consistently greater in the Eastern Caribbean, particularly $\left(>0.10 \mu\right.$ a $^{-1}$ ) at the coastal stations (P12, 10,16,17, 18,18A, 20); while especially low values $\left(0.02 \mu \mathrm{g}\right.$ at $\left.\mathrm{l}^{-1}\right)$ occurred South of Haiti (stations $\left.25-27\right)$. $\mathrm{NO}_{3}-\mathrm{N}$ was not detected in the central region, which separated the relatively nitrate rich Western and Eastern Caribbean stations. Station 16, near the Eastern tip of the Dominican Republic, was especially distinctive by the highest recorded nitrate and phosphate levels and the presence of $>35.0 \%$ water. The river runoff detectable at station 19 was accompanied by a lower $\mathrm{PO}_{4}-\mathrm{P}$ level $\left(0.07 \mu \mathrm{g}\right.$ at $\left.\mathrm{l}^{-1}\right)$ than that measured in other coastal waters; $\mathrm{NO}_{3}-\mathrm{N}$ was not detectable.

The general surface circulation, which varies seasonally, exhibits a Northwest drift during October (Wüst 1964) for most of the survey area. A branch flows Northwards through the Mona Passage near the Eastern tip of the Dominican Republic. It is unknown whether this contributes to the unique conditions found at station 16. A Southward flowing current occurs near the coast off the Western tip of Haiti which can flow Eastwards (as in July). It is unknown to what extent this current contributes to the swath of $<35.0 \%$ water in which station 26 is situated (Fig. 2).

The general hydrographic conditions suggest that several different water types were bioassayed in the experiments.

\section{Bioassay experiments with Caribbean Sea water}

\section{Bacteriastrum byalinum}

The Bacteriastrum byalinum bioassay was not carried out after station 14 (Fig. 3, Table 7) for the reasons presented in the section "Material and Methods". As in the Phosphorescent Bay experiments, inoculum mortality occurred in the u $\mathrm{nen} \mathrm{ich}$ ed samples from stations 10,11 and 12. Survival, without growth, occurred at station 14. Neither the complete enrichment (ALL) nor any modification eliminated this toxicity, 
Table 7

Growth response of Bacteriastrum byalinum in various nutrient enrichments of Caribbean surface water from stations $10,11,12$ and 14 relative to inoculum $(A)$ and complete $(A L L)$ enrichment (B) responses

\begin{tabular}{|c|c|c|c|c|}
\hline \multirow{2}{*}{ Enrichment } & \multicolumn{4}{|c|}{ Stations } \\
\hline & 10 & 11 & 12 & 14 \\
\hline \multicolumn{5}{|l|}{ Response $\mathrm{A}$} \\
\hline NONE & 0.45 & 0.29 & 0.27 & 1.05 \\
\hline ALL & 0.60 & 0.42 & 0.42 & 0.02 \\
\hline ALL-P & 0.48 & 0.64 & 0.45 & 0.73 \\
\hline ALL-N & 0.54 & 0.45 & 0.76 & 0.92 \\
\hline$A \_x-S i$ & 0.69 & 0.30 & 0.20 & 0.27 \\
\hline $\mathrm{ALL}-\mathrm{Fe}+\mathrm{Na}_{2} \mathrm{EDTA}$ & 0.27 & 0.45 & 0.16 & 0.72 \\
\hline ALL-TM & 0.48 & 0.50 & 0.43 & 0.57 \\
\hline ALL-VITS & 0.30 & 0.27 & 0.24 & 0.66 \\
\hline \multicolumn{5}{|l|}{ Response B } \\
\hline NONE & 0.77 & 0.69 & 0.65 & 46.30 \\
\hline ALL-P & 0.82 & 1.52 & 1.08 & 32.00 \\
\hline ALL-N & 0.91 & 1.06 & 1.81 & 40.50 \\
\hline AxL-Si & 1.15 & 0.71 & 0.48 & 12.00 \\
\hline ALL-Fe+Na2EDTA & 0.44 & 1.08 & 0.38 & 31.50 \\
\hline ALL-TM & 0.80 & 0.65 & 0.56 & 25.00 \\
\hline ALL-VITS & 0.48 & 1.19 & 1.02 & 29.00 \\
\hline
\end{tabular}

although a slightly improved response relative to All accompanied the omission of nitrate and phosphate at stations 11 and 12 , and most nutrients at station 14 . This suggests that some nutrients compounded the natural inhibitory quality of the water mass, while others supported growth.

The influence of the various nutrient omissions on growth relative to All (Table 7) suggests that inhibitory nutrient levels frequently resulted from nutrient addition.

\section{Thalassiosira rotula}

The Caribbean surface waters were usually toxic to Thalassiosira rotula, irrespective of the nutrient enrichment treatment (Fig. 3, Tables 8 and 9). Growth occurred in only $16(14 \%)$ of the 112 bioassay experiments, and at 5 of the 14 stations. Only the water mass at stations 24,25 and 26 , located near Haiti, clearly supported growth. Isolated instances of growth occurred, as at station 15 in AlL-Si, and at station 19 (influenced by river run off) after iron (with EDTA present) omission.

The general unsuitability of Caribbean surface water for Thalassiosira rotula growth (even after enrichment) was independent of water mass type, land mass influence, or river run off, insofar as these were distinguishable hydrographically or through station location. The conspicuous differences in water quality at stations 24-26 from that elsewhere, suggested by the growth of Thalassiosira rotula, are likewise not predictable from the hydrographic conditions (Fig. 2, Table 2). Station 24 was the only location where growth with out enrichment occurred. It was not further improved after complete enrichment (ALL) which promoted auxospore forma- 
Table 8

Growth response of Thalassiosira rotula in various nutrient enrichments of Caribbean surface water at stations 22 and 24 to 27 , relative to the inoculum

\begin{tabular}{|lcrrrc|}
\hline Enrichment & 22 & 24 & 25 & 26 & 27 \\
\hline NoNE & 0.28 & 1.09 & 0.79 & 0.50 & 0.19 \\
ALL & 0.15 & 1.08 & 0.79 & 2.11 & 0.54 \\
ALL-P & 0.15 & 0.82 & 0.53 & 1.69 & 0.50 \\
ALL-N & 0.11 & 1.90 & 0.33 & 0.22 & 0.63 \\
ALL-Si & 0.09 & 7.58 & 0.35 & 0.77 & 0.32 \\
ALL-Fe+NagEDTA & 0.26 & 21.30 & 31.07 & 16.90 & 0.42 \\
ALL-TM & 0.20 & 24.42 & 20.56 & 0.77 & 0.54 \\
ALL-VITS & 0.11 & 7.87 & 11.96 & 2.81 & 0.60 \\
\hline
\end{tabular}

tion. However, the omission of nitrate, silicate, vitamins, and especially iron (with (EDTA present), and trace metals markedly stimulated growth (Table 8, Fig. 3).

Growth occurred at station 25 only after the omission of iron (with EDTA added), trace metals and vitamins; omission of the other nutrients from ALL limited growth. At station 26 growth with ALL was significantly exceeded following the omission of iron (with EDTA added), whereas the omission of nitrate, silicate and trace metals limited growth (Table 8).

These results suggest that a natural nutrient limitation of growth of Thalassiosira rotula occurred, which could be corrected by enrichment. And also, that certain nutrients, which varied from station to station, which were initially within tolerable limits were exceeded upon enrichment and led to growth inhibition. There is no evident hydrographic reason for the failure of station 27 to support growth (Table 8). Perhaps here, as at most locations, specific nutrient inhibition coupled with general nutrient

Table 9

Growth response of Thalassiosira rotula in various nutrient enrichments of Caribbean surface water collected during 13-20 November, 1963, relative to complete enrichment (ALL) response

\begin{tabular}{|cccccccc|}
\hline Stations & NoNE & ALL-P & ALL-N & ALL-Si & $\begin{array}{c}\text { ALL-Fe } \\
\text { (+Na2 } \\
\text { EDTA) }\end{array}$ & ALI-TM & ALL-VITS \\
\hline 10 & 0.68 & 0.62 & 0.24 & 1.44 & 1.02 & 0.75 & 0.69 \\
11 & 0.56 & 0.87 & 0.75 & 1.38 & 1.19 & 2.13 & 1.19 \\
12 & 0.42 & 0.65 & 0.92 & 1.56 & 1.94 & 5.10 & 1.67 \\
14 & 1.88 & 0.55 & 0.41 & 2.73 & 1.73 & 2.59 & 0.96 \\
15 & 1.02 & 0.73 & 0.97 & 1.54 & 0.58 & 0.78 & 0.51 \\
16 & 0.94 & 1.22 & 0.58 & 0.81 & 1.19 & 0.87 & 0.92 \\
18 & 1.34 & 0.91 & 0.74 & 0.61 & 0.85 & 0.69 & 0.97 \\
19 & 1.10 & 1.06 & 0.34 & 0.67 & 2.91 & 1.53 & 2.00 \\
21 & 1.26 & 0.61 & 0.61 & 0.87 & 1.26 & 1.43 & 0.91 \\
22 & 1.88 & 1.00 & 0.75 & 0.63 & 1.75 & 1.31 & 0.75 \\
24 & 1.01 & 0.76 & 1.76 & 7.02 & 19.72 & 22.55 & 7.90 \\
25 & 1.00 & 0.67 & 0.42 & 0.44 & 39.33 & 26.03 & 15.14 \\
26 & 0.24 & 0.80 & 0.10 & 0.36 & 8.00 & 0.36 & 1.32 \\
27 & 2.81 & 0.93 & 1.16 & 0.59 & 0.77 & 1.00 & 1.12 \\
\hline
\end{tabular}




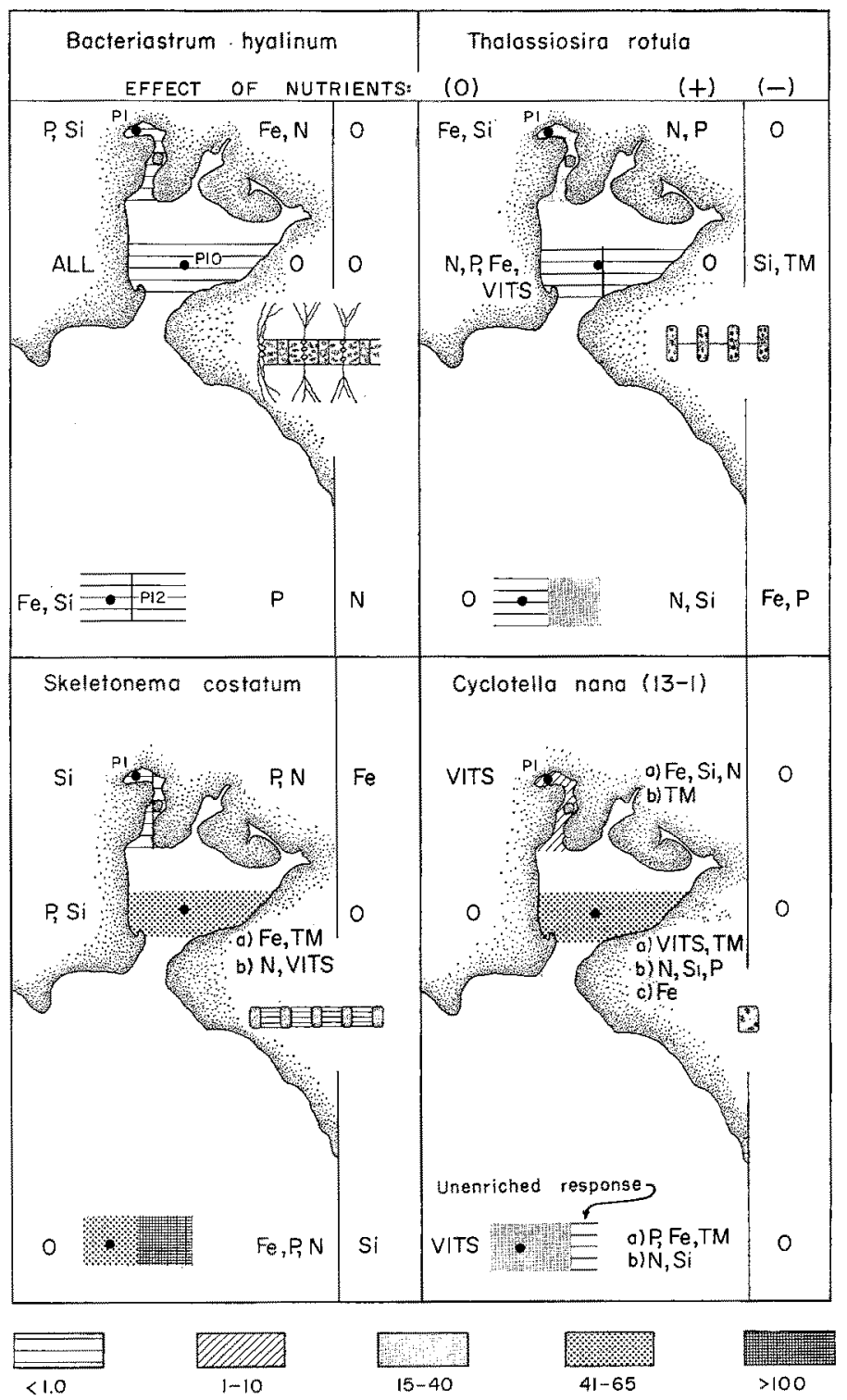

Fig. 4: General results of the enrichment experiments in Phosphorescent Bay. Nutrients were assigned as having a stimulatory $(+)$, inhibitory $(-)$, or neutral $(0)$ effect only if the response to that treatment was $\pm 50 \%$ of that with complete enrichment (ALL) when related to the inoculum. The ALL, TM (trace metal) and ViTs (vitamin) compositions are as given in Table 3. Where $O$ is entered in the nutrient effect columns, no nutrient had that particular influence. Nutrients preceded by a) were especially important in causing the effect; to a lesser extent when preceded by $b$ ). Where the magnitude of response is divided, the left side of the shaded area represents the response in the complete enrichment ( $A_{L}$ ) relative to the inoculum, and the right side represents growth when the nutrient causing the maximum inhibition of those listed in the (-) column was omitted from the medium. Note exception to this at station P12 for Cyclotella nana (13-1). Undivided shaded areas are presented when no nutrient was inhibitory, the shading intensity then used represents the response in ALL, as given above 
limitation, or specific nutrient inhibition stronger in effect than growth promotion of added nutrients, caused the widespread inhibition of Thalassiosira rotula (and Bacteriastrum byalinum).

Station to station variations and regional differences in the influence of various nutrient omissions on growth, relative to that in ALL, occurred (Table 9). For example, silicate omission was favorable only in the Eastern Caribbean (with one exception); vitamins principally in the Western Caribbean; and iron (with EDTA added) and trace metals generally (Table 9, Fig. 3). Chlorotic cells were frequently found.

\section{DISCUSSION}

These bioassay experimental results are intrinsically of more general than specific interest because of the methodological approach, including the bioassay species used, and because of incomplete ecological examination. But also, because they deal with the ambiguous, complex issue of "water quality", which includes the various nutritional, physico-chemical, stimulatory, inhibitory, etc., reactions which influence phytoplankton growth.

The interpretation of nutrient enrichment experiments is handicapped by several effects partly related to water quality and worthy of brief mention. These include the facts that (1) nutrients are added to the original level (usually unknown); (2) nutrient interactions sometimes influence assimilation; (3) the addition of chelators may influence the natural constitutents and also induce unknown changes in water quality; and (4) naturally occurring chelators may influence the nutrient additions and also induce unknown changes in water quality which influence growth. These complications can be illustrated.

Assume a nutrient to be present naturally in tolerable concentrations. Addition of this nutrient may now increase its total concentration to above tolerable levels, and no growth occurs. This result may be falsely interpreted as meaning that growth is independent of that nutrient when, in fact, inhibition is occurring. If no growth occurs when the added nutrient is, for example, phosphate (whose assimilation is dependent upon nitrate) a similar conclusion might be reached; however, it might be due to a lack of sufficient nitrate. The influence of added chelators on water quality through modification of the natural constituents has been clearly shown elsewhere (JoHnston 1964, Smayda 1964). That naturally occurring chelators can also influence added nutrients is suggested by the influence of polypeptides on effective $\mathrm{CuSO}_{4}$ application, needed to control blue-green algal blooms (Fogg \& Westlake 1955). The problem of the influence of nutrient concentration on the growth rate is an additional complication. A complicated experimental design with a large matrix can partially eliminate some of these pitfalls. The projected use of such observations will determine both the experimental design and ecological observations necessary to facilitate interpretation and application of the results to natural situations.

The present bioassay experiments were not designed to help explain the remarkable concentration of dinoflagellates in Phosphorescent Bay. However, they are partly concerned with the question of whether this dinoflagellate and mangrove-modified 
embayment can support good diatom (as a group) growth, floristic observations (MARGALEF 1957, 1961) notwithstanding. The principal concern of this discussion is to evaluate the primary experimental objective, namely to examine the general question of to what extent small scale "chemical patchiness" can occur in the growth supporting potential of a water mass or region for different species. Two of the assay diatoms (Cyclotella nana [13-1] and Thalassiosira rotula) might be allochthonous to Phosphorescent Bay water; Bacteriastrum hyalinum and Skeletonema costatum are autochthonous, but of different physiological race (Narragansett Bay).

Gold (1965) conducted bioassay experiments in Phosphorescent Bay, using water from an undisclosed location and depth. The responses of the bioassay diatoms Amphiprora paludosa, Chatoceros simplex, Cyclotella nana and Skeletonema costatum were determined after 10 days' growth. A. paludosa and C. simplex were of "Puerto Rican origin".

The November, 1963, surface waters of Phosphorescent Bay supported luxuriant growth of the bioassay diatoms, with or without enrichment. However, these waters did not equally favor the growth of all species. These differences in water quality are clearly evident in the responses of the 4 diatoms summarized in Figure 4. All waters were toxic to Bacteriastrum byalinum, but favorable to Cyclotella nana. Thalassiosira rotula was especially favored by the innermost, turbid, phosphate-rich mangrove backwater; this was toxic to Skeletonema costatum which thrived at the other stations generally inhibitory to $T$. rotula. Arrayed in decreasing order of suitability for growth, the species responded at the stations as follows (those to right of solid vertical line were always inhibited, those to right of broken line usually):

P1 Thalassiosira rotula $>$ Cyclotella nana $\rangle \mid$ Bacteriastrum byalinum $>$ Skeletonema costatum

P10 Skeletonema costatum $>$ Cyclotella nana $>\mid$ Bacteriastrum byalinum $\rangle$ Thalassiosira rotula

P12 Skeletonema costatum $>$ Cyclotella nana $>$ Thalassiosira rotula $>$ I Bacteriastrum byalinum

Overall, the response was: Cyclotella nana $>$ Skeletonema costatum $>$ Thalassiosira rotula $>\mid$ Bacteriastrum byalinum.

The clear, general inhibition of Bacteriastrum byalinum (as in the assayed Caribbean waters), as well as that of the innermost, mangrove backwater (P1) for Skeletonema costatum, and the mid-bay (P10) and, partially, the coral reef water (P12) for Thalassiosira rotula, suggest the occurrence of a natural, selective inhibitor. Failure of growth, even with selective nutrient omission, is consistent with this conclusion. GoLD (1965) found no evidence that natural inhibitors prevented growth of his 4 bioassay diatoms. The release of organically discolored waters from the mangrove swamps into Phosphorescent Bay has been observed by ODum et al. (1959). The author has observed copious liberation of tea colored substances discoloring the water of the mangrove bordered waters near Cananéia, Brazil $\left(25^{\circ} \mathrm{S}, 48^{\circ} \mathrm{W}\right)$. These were demonstrated (unpublished) to emanate from the mangrove Languncularia sp., a plant noted for its production of tannins. These substances, which have been found to inhibit the growth of certain phytoplankton species (CRAIGIE \& MCLACHLAN 1964), might be involved in the apparent inhibition noted above. However, it is unlikely that they are contribu- 
tory to the general toxicity of Caribbean waters for $T$. rotula (Fig. 3) and B. byalinum (Table 7).

Nutrient addition sometimes caused partial or significant inhibition (Fig. 4). This is most clearly illustrated by the omission of silicate at station P12 which stimulated growth of Skeletonema costatum 136 fold relative to the inoculum. This was about 2.5 fold greater than that in All (Table 4). Gold (1965) found that silicate addition always reduced growth, which he suggested might be attributable to the co-precipitation of an essential trace metal along with a slight silicate precipitate. However, silicate addition inhibited growth in only $17 \%$ (2 of 12) of my Phosphorescent Bay experiments, and only twice in the Caribbean experiments (Fig. 2, Tables 7,8). In the former area, it stimulated growth in $33 \%$, and had no apparent effect on the remaining $50 \%(6)$. The frequency of inhibition by phosphate and iron matched that obtained with silicate. Cyclotella nana was never demonstrably inhibited by any nutrient addition, and Thalassiosira rotula most frequently (Fig. 4). Trace metal and vitamin addition significantly inhibited growth of $T$. rotula at the "favorable" stations 24 and 25 in the Caribbean, as did iron at stations 24-26 (Fig. 2, Table 8). The simplest explanation of these results is that the nutrient additions increased the initial concentrations above tolerable limits (as in the case of nitrate, phosphate, and vitamins) and/or induced physico-chemical changes deleterious to growth (as with silicate, iron and the trace metal mixture).

Nutrient limitation was also demonstrated on a major scale, particularly for Cyclotella nana (13-1) at station P12 (Fig. 4, Table 6), and for specific nutrients. Nitrate limitation occurred in $75 \%$ (9) of the Phosphorescent Bay experiments where tested, phosphate and iron in $50 \%$, and silicate in $33 \%$. The trace metal and vitamin mixtures were omitted in 6 experiments. Trace metal omission limited growth in $66 \%$ of these, and vitamin omission twice $(33 \%)$. Both instances of vitamin limitation occurred at station P10 with Skeletonema costatum and Cyclotella nana, an effect surprising in view of the fairly high concentrations of soluble vitamin $\mathrm{B}_{12}$ in Phosphorescent Bay (BurkHolder \& BurkHolder 1958, Gold 1965). Gold reported that the omission of his trace metal mixture (Fe, $\mathrm{Zn}$, Co, Mn, Bo plus EDTA) from the complete enrichment limited the cell yield of all bioassay species except Chaetoceros simplex, which required added nitrate for growth.

These experiments demonstrate that (1) basic station to station differences in water quality exist in Phosphorescent Bay for a given species, and on a general level in the Caribbean for Thalassiosira rotula; (2) significant species differences occurred in their tolerance of and requirements for growth in these waters. This demonstrates that small scale "chemical patchiness" in the growth supporting potential of a water mass can occur (Fig. 4). The different responses relative to ALL accompanying nutrient omission (Tables 5, 7 and 9), and the various offshore gradients in response (discussed previously) also reflect this. The effect was observed in both the Phosphorescent Bay and Caribbean surveys, and for all species. The results of the unen riched assays indicate that this was a natural phenomenon. The effect is modified, though still detectable, upon enrichment. The response is then a balance between the combined natural and induced inhibitory properties and the growth promoting properties of the sample. 
Small scale patchiness in phytoplankton distribution is now well established (CASsIE 1963). It is unknown to what extent this reflects the "chemical patchiness" in growth-supporting potential suggested by these bioassay experiments, in addition to an influence of micro-convection and turbulence.

There was no apparent correlation between the bioassay results and the measured hydrographic parameters, both regionally and, as in Phosphorescent Bay, on a small scale. This, as "chemical patchiness", is also evident in the unpredictable station to station variations in the effect of a given nutrient, or nutrient combination, on the growth of a given species, and the species differences in response (Fig. 4, Tables 4-9). The surprising growth of the oceanic species Cyclotella nana (13-1) in the dirty, phosphate rich mangrove backwater station (P1) (which was toxic to the ubiquitous inshore diatom Skeletonema costatum) also partially illustrates this. It is also evident on a large scale in the unique Thalassiosira rotula response at stations $24-26$ in the Caribbean survey, and in the different responses exhibited by Skeletonema costatum in that survey (SMAYDA, in preparation).

This observation carries an important implication. If it is generally valid, it suggests an inherent weakness in the traditional approach of trying to account for the observed successional and distributional patterns of phytoplankton species from an analysis of the prevailing hydrographic conditions. This dilemma suggests that nutrient enridiment experiments are a desirable additional approach to aid in the interpretation of ecological observations (see Skulberg 1966). However, where problems of species succession and distribution in natural waters are being investigated, such an approach (with appropriate modification) would appear to be essential. The technique, accordingly, warrants further development and application.

\section{SUMMARY}

1. The growth potential of November surface waters collected at 3 stations in Phosphorescent Bay, Puerto Rico, for the diatoms Bacteriastrum byalinum, Cyclotella nana (13-1), Skeletonema costatum, and Thalassiosira rotula was determined after enrichment in various ways.

2. Enrichment experiments were also conducted at 14 stations in the Caribbean Sea using Thalassiosira rotula as the bioassay diatom, and at 4 stations using Bacteriastrum byalinum.

3. Marked differences in response occurred, based on growth for 5 days at $20^{\circ} \mathrm{C}$ and $700 \mathrm{ft}-\mathrm{c}$ of continuous, artificial illumination. All surface waters were toxic to Bacteriastrum byalinum; Thalassiosira rotula grew well only in the innermost waters of Phosphorescent Bay, and at 3 of the 14 Caribbean stations. Skeletonema costatum grew only at 2 of the 3 Phosporescent Bay stations (the converse of the Thalassiosira rotula response), and Cyclotella nana (13-1) at all stations.

4. Growth was either stimulated, inhibited or unaffected by certain nutrients; a combination of natural nutrient limitation and inhibition influenced growth.

5. Transect gradients occurred in the relative influence of various nutrients on growth, such as the omission of silicate from the complete enrichment which led to a progres- 
sive, offshore improvement in growth of Skeletonema costatum, whereas phosphate omission limited growth of Bacteriastrum byalinum.

6. The occurrence of marked short scale differences in water quality ("chemical patchiness") is suggested by the station to station variations in effect of a given nutrient or nutrient combination on the growth of a given species and growth differences between species. These effects were not predictable from the hydrographic observations. Individual species responses to a specific nutrient enrichment were likewise unpredictable from a given species' known bioassay response.

7. The relevance of the demonstrated occurrence of "chemical patchiness" to the examination of the general problems of succession and distribution of species is briefly discussed.

\section{LITERATURE CITED}

Bioluminescent bays of Puerto Rico, The, 1968. A plan for their preservation and use. U.S. Dept. of the Interior, National Park Service, Washington, D.C., 48 pp.

BRAarud, T., 1962. Species distribution in marine phytoplankton. J. oceanogr. Soc. Japan 20th Anniversary Vol., 628-649.

Burkholder, P. R. \& Burkholder, L. M., 1958. Studies on B vitamins in relation to productivity of the Bahía Fosforescénte, Puerto Rico. Bull. mar. Sci. Gulf Caribb. 8, 201-223.

- - \& Almodóvar, L. R., 1967. Carbon assimilation of marine flagellate blooms in neritic waters of southern Puerto Rico. Bull. mar. Sci. Gulf Caribb. 17, 1-15.

CAssie, R. M., 1963. Microdistribution of plankton. Oceanogr. mar. Biol. A. Rev. 1, 223-252.

Clarke, G. L. \& Breslau, L. R., 1960. Studies of luminescent flashing in Phosphorescent Bay, Puerto Rico, and in the Gulf of Naples using a portable bathyphotometer. Bull. Inst. océanogr. Monaco 57 (1171), 1-32.

COKER, R. E. \& GonZÁLEZ, J. G., 1960. Limnetic copepod populations of Bahía Fosforescénte and adjacent waters, Puerto Rico. J. Elisha Mitchell scient. Soc. 76, 8-28.

Craigie, J. S. \& McLachlan, J., 1964. Excretion of colored ultraviolet-absorbing substances by marine algae. Can. J. Microbiol. 42, 23-33.

FogG, G. E. \& WeSTLAKE, D. F., 1955. The importance of extracellular products of algae in fresh water. Verh. int. Ver, theor. angew. Limnol. 12, 219-232.

Glynn, P. W., Almodóvar, L. R. \& González, J. G., 1964. Effects of hurricane Edith on marine life in La Parguera, Puerto Rico. Caribb. J. Sci. 4, 335-345.

GoLD, K., 1965. A note on the distribution of luminescent dinoflagellates and water constituents in Phosphorescent Bay, Puerto Rico. Ocean Sci. Ocean Engng. 1, 77-80.

González, J. G., 1967. Primary productivity of the neritic and offshore waters of western Puerto Rico. U.S. Office of Naval Research, Washington, D.C., 11 pp. NONR-4318(O0).

Guillard, R. R. L. \& Ryther, J. H., 1962. Studies of marine planktonic diatoms. I. Cyclotella nana Hustedt and Detonula confervacea (Cieve) Gran. Can. J. Microbiol. 8, 229-239.

Johnston, R., 1964. Sea water, the natural medium of phytoplankton. II. Trace metals and chelation, and general discussion. J. mar. biol. Ass. U.K. 44, 87-110.

Margalef, R., 1957. Fitoplancton de las costas de Puerto Rico. Investigacion pesq. 6, 39-52.

- 1961. Hidrografía y fitoplancton de un área marina de la costa meridional de Puerto Rico. Investigacion pesq. 18, 33-96.

Odum, H. T., Burkholder, P. R. \& Rrvero, J. A., 1959. Measurements of productivity of turtle grass flats, reefs, and the Bahía Fosforescénte of southern Puerto Rico. Publ. Inst. mar. Sci. Univ. Tex. 6, 159-170.

PARR, A. E., 1935. Report on hydrographic observations in the Gulf of Mexico and the adjacent straits made during the Yale Oceanographic Expedition on the "Mabel Taylor" in 1932. Bull. Bingbam oceanogr. Coll. 5 (1), 1-93. 
Poole, H. H. \& Atkins, W. R. G., 1929. Photo-electric measurements of submarine illumination throughout the year. J. mar. biol. Ass. U.K. 16, 297-324.

SkULbERG, O. M., 1966. Algal cultures as a means to assess the fertilizing influence of pollution. Int. Conf. Wat. Pollut. Res. 3 (Sect. 1, No 6), 1-15.

SmAyda, T. J., 1957. Phytoplankton studies in lower Narragansett Bay. Limnol. Oceanogr. 2, 342-358.

- 1964. Enrichment experiments using the marine centric diatom Cyclotella nana (clone 13-1) as an assay organism. In: Experimental marine ecology. Proceedings of a Symposium held at the Univ. of Rhode Island, 1963. Narragansett Marine Laboratory, Kingston, R. I., 25-32. (Occ. Publ. 2.)

- 1970. Some morphological and experimental observations on Skeletonema costatum (Grev.) Cleve. (In prep.)

TAKANO, H., 1960. Plankton diatoms in the eastern Caribbean Sea. J. oceanogr. Soc. Japan 16, 180-184.

Wüst, G., 1964. Stratification and circulation in the Antillean-Caribbean basins. Pt I. Columbia Univ. Press, New York, 201 pp. ('Vema' Res. Ser. 2.)

Author's address: Prof. Dr. T. J. SMaYda

Graduate School of Oceanography

University of Rhode Island

Kingston, Rhode Island 02881, USA 